\title{
Penerapan Sistem Persamaan Diferensial Linier pada Simulasi Debit Air pada Pipa
}

Rustam Efendia, Diang Sagita ${ }^{\mathrm{b}}$

aDepartment of Mechanical and Biosystem Engineering, IPB University, Indonesia.

e-mail: rustamefendi032@gmail.com

bPusat Penelitian Teknologi Tepat Guna - Lembaga Ilmu Pengetahuan Indonesia

JL. K.S. Tubun No. 5 Subang, Jawa Barat

e-mail: dian043@lipi.go.id

Kata kunci:

analisis

numerik;

metode

Euler;

persamaan

diferensial;

sistem

instalasi

pipa.

\begin{abstract}
ABSTRAK
Salah satu permasalahan dalam kehidupan sehari-hari yang cukup rumit untuk diselesaikan adalah sistem aliran fluida (air) dalam bejana bertingkat. Pada penelitian ini, telah dilakukan pembuatan model sistem persamaan diferensial linear (SPDL) yang menggambarkan aliran air dari sistem instalasi air dengan tangki bertingkat serta membandingkan hasil simulasi numerik dari model dengan hasil eksperimen. Model SPDL dibangun dengan melibatkan observasi lapang secara langsung untuk menentukan nilai konstanta model $\left(C_{1}, C_{2}\right.$ dan $\left.C_{3}\right)$. Model yang telah dibangun disimulasikan secara numerik menggunakan metode Euler dengan 4 skenario nilai konstanta. Hasil menunjukkan bahwa volume tangki A dan B serta laju perubahan volume airnya telah berhasil digambarkan oleh model SPDL yang telah dibangun dengan hasil yang paling mendekati hasil eksperimen adalah nilai $C_{1}$ sebesar 0.01323 dan $C_{2}$ sebesar 0.01091 dengan nilai RMSE 0.2599.
\end{abstract}

\section{ABSTRACT}

One of the problems in daily life that are quite complicated to solve is the fluid flow system (water) in a muliterilevel vessel. In this study, a model of a system of linear differential equations (SPDL) has been developed which describes the flow of water from a water installation system with a muliterilevel vessel and compared the resuliters of the numerical simulation with the experimental resuliters. The SPDL model was builiter by involving direct field observations to determine the model constants $\left(C_{1}, C_{2}\right.$, and $\left.C_{3}\right)$. The model that has been builiter was simulated numerically using the Euler method with 4 scenarios of constant values. The resuliters show that the volumes of tanks $A$ and $B$ and the rate of change of their water volume have been successfully described by the SPDL model that has been builiter with the resuliters closest to the experimental resuliters, namely the $C_{1}$ value of 0.01356 and $C_{2}$ of 0.01091 with RMSE value 0.2599.

\section{PENDAHULUAN}

Suatu sistem yang cukup kompleks dimana perubahan terjadi setiap saat (satuan waktu) umumnya sulit dipecahkan dengan perhitungan Aljabar sederhana. Salah satu permasalahan dalam kehidupan sehari-hari yang cukup rumit adalah sistem aliran fluida (air) dalam bejana bertingkat (Gambar 1). Dalam kasus ini, volume air pada tangki A dan B akan terus mengalami perubahan setiap satuan waktu akibat adanya input air yang masuk dan output air yang keluar, begitu juga pada tangki B. Hal yang menarik dari kasus ini adalah laju pengeluaran air dari tangki A dan tangki B sangat dipengaruhi oleh volume di tangki masing-masing sebagaimana berlaku hukum Torricelli [1]. Hukum Torricelli, juga dikenal sebagai teorema Torricelli, adalah teorema dalam dinamika fluida yang berkaitan dengan kecepatan fluida yang mengalir dari sebuah lubang yang dipengaruhi oleh ketinggian air terhadap lubang pengeluaran. Hal ini dapat dilihat pada ilustrasi Gambar 2. 
Secara teori, kasus sebagaimana Gambar 1 memungkinkan terjadinya perubahan volume dan juga debit setiap saat karena dipengaruhi oleh beberapa faktor sebagai contoh volume air di tangki A dipengaruhi oleh input air dan output air. Namun dengan berlakunya hukum Torricelli, output air tangki A juga dipengaruhi oleh volume air di tangki A itu sendiri sehingga kasusnya menjadi lebih kompleks.

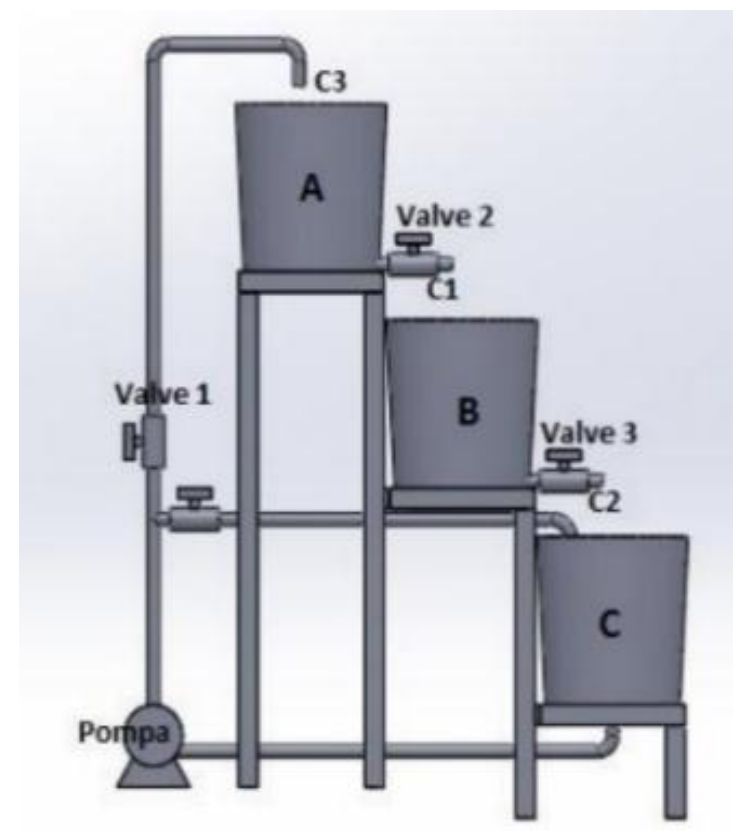

Gambar 1 Sistem instalasi aliran air pada tangki bertingkat
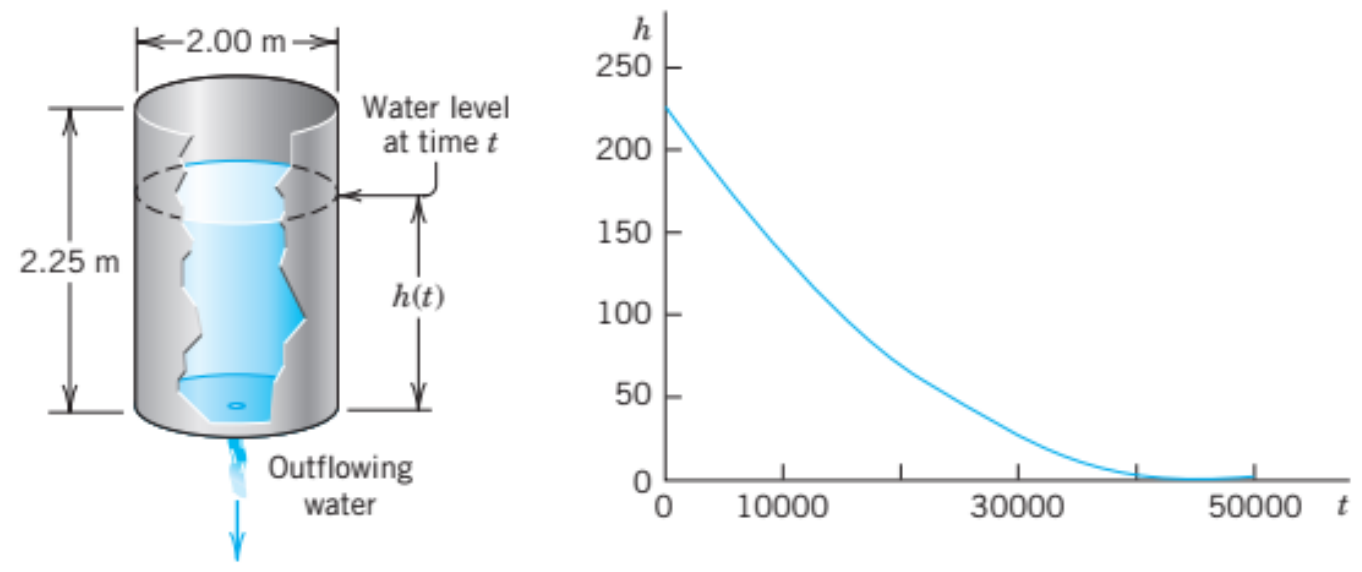

Gambar 2 Ilustrasi kecepatan air keluar dari tangki berdasarkan hukum Toricelli [1]

Dengan demikian, untuk memodelkan kasus aliran air ini diperlukan suatu pendekatan sistem persamaan diferensial linear (SPDL) yang bergantung kepada waktu. Persamaan diferensial adalah persamaan yang memuat atau melibatkan turunan (derivative) atau diferensial dari fungsi yang tidak diketahui [2]. Persamaan diferensial memiliki aplikasi yang luas dalam berbagai disiplin ilmu teknik dan sains. Secara umum, pemodelan diaplikasikan pada variasi besaran fisika seperti suhu, tekanan, perpindahan, kecepatan, tegangan, regangan, arus dan besaran lainnya yang bergantung kepada waktu atau lokasi, atau keduanya [3]. Dalam kasus penelitian ini, model umum dari SPDL yang diilustrasikan oleh Gambar 1 dapat dilihat pada persamaan (1)-(3). Sebuah sistem persamaan diferensial terdiri dari sebuah himpunan persamaan-persamaan yang simuliteran mencakup beberapa turunan dari suatu fungsi. 


$$
\begin{aligned}
& Q=C_{3}=\frac{V}{t} \\
& \frac{\partial V A}{\partial t}=C_{3}-C_{1} \times V A \\
& \frac{\partial V B}{\partial t}=C_{1} \times V A-C_{2} \times V B
\end{aligned}
$$

Dimana, $Q$ adalah laju aliran air (liter/s), $V A$ adalah volume air pada tangki A (liter), VB adalah volume air pada tangki B (liter); $t$ adalah waktu (s); $C_{1}$ dan $C_{2}$ adalah konstanta.

Dalam penelitian ini, terapan matematika yang digunakan untuk mencari solusi persamaan SPDL ini adalah metode numerik, yakni suatu teknik penyelesaian yang diformulasikan secara matematis dengan cara operasi hitungan dan dilakukan secara berulang-ulang [4]. Penelitian ini bertujuan untuk membuat model persamaan diferensial linear dalam kasus aliran air pada pipa dan tangki air sebagaimana Gambar 1 serta membandingkan hasil keluaran dari model secara numerik dan eksperimental. Penelitian ini diharapkan dapat bermanfaat dalam upaya menerapkan sistem persamaan diferensial linear dalam aplikasi sistem instalasi air dengan tangki bertingkat sehingga perubahanperbuhan yang terjadi pada sistem (debit, volume dan laju aliran) dapat dimodelkan dan diprediksi melalui pendekatan numerik.

\section{METODE PENELITIAN}

Peralatan yang digunakan dalam penelitian ini adalah sistem instalasi air yang terdiri atas tiga buah tangki, satu buah pompa air sentrifugal, dan satu buah kamera perekam. Sementara bahan yang digunakan adalah air sebagai objek fluida yang dialirkan.

\subsection{Prosedur Penelitian}

Unit instalasi pipa yang diuji terdiri dari tiga buah tangki air (A, B dan C), empat buah valve yang terhubung dengan instalasi pipa, dan satu buah pompa air sentrifugal (Gambar 3). Pengujian ini dimulai dengan mengisi tangki $C$ hingga penuh, kemudian pompa dinyalakan. Debit air pompa yang masuk ke tangki A diukur untuk menentukan nilai $Q$ atau $C_{3}$ (liter/s). $C_{3}$ diukur dengan cara membiarkan pompa mengisi tangki A sampai ketinggian volume tertentu dengan kondisi valve 2 tertutup. Bukaan valve 1 dibuka setengah agar air di tangki $C$ tidak cepat habis. Nilai $C_{3}$ dihitung menggunakan persamaan (4). $C_{3}$ ditentukan dengan menghitung perubahan volume per 3 detik sampai volume tangki A mencapai 20 liter.

$$
C_{3}=\frac{\left(V A_{n}-V A_{n-1}\right)}{\left(t_{n}-t_{n-1}\right)}
$$

Selanjutnya, untuk mencari nilai konstanta $C_{1}$ dan $C_{2}$, diperlukan observasi terhadap besarnya laju perubahan volume air di tangki A $(\partial V A / \partial t)$ dan di tangki B $(\partial V B / \partial t)$. Observasi dimulai dengan membuka valve 2 dan valve 3 secara penuh sehingga airnya mengalir. Pada kondisi ini, air di tangki A memiliki volume 20 liter. Laju $\partial V A / \partial t$ dan $(\partial V B / \partial t)$ didapatkan dari hasil pengamatan perubahan volume dalam waktu 180 detik (3 menit) di tangki A dan B pada kondisi valve 1, 2, dan 3 dibuka sesuai uraian di atas. Laju $\partial V A / \partial t$ dan $(\partial V B / \partial t)$ masing-masing dihitung menggunakan persamaan (5) dan (6). Selanjutnya untuk menghitung nilai konstanta $C_{1}$ dan $C_{2}$, digunakan persamaan (7) dan (8).

$$
\begin{aligned}
& \frac{\partial V A}{\partial t_{n}}=\frac{\left(V A_{n}-V A_{n-1}\right)}{\left(t_{n}-t_{n-1}\right)} \\
& \frac{\partial V B}{\partial t_{n}}=\frac{\left(V B_{n}-V B_{n-1}\right)}{\left(t_{n}-t_{n-1}\right)}
\end{aligned}
$$




$$
\begin{gathered}
C_{1 n}=\frac{\left(C_{3}-\frac{\partial A}{\partial t_{n}}\right)}{V A_{n}} \\
C_{2 n}=\frac{\left(C_{3}-\frac{\partial A}{\partial t_{n}}-\frac{\partial B}{\partial t_{n}}\right)}{V A_{n}}
\end{gathered}
$$

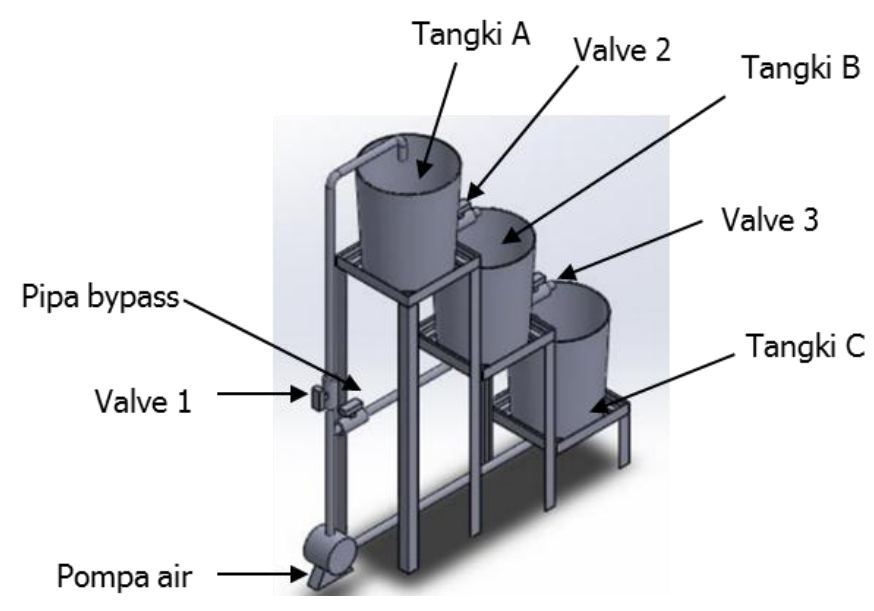

Gambar 3 Tampak isometri dari sistem instalasi air

\subsection{Analisis Numerik}

Analisis numerik dilakukan pada model yang telah dibangun berdasarkan nilai konstanta yang diperoleh yaitu $C_{1}, C_{2}$ dan $C_{3}$. Model yang telah dibangun diuji secara numerik mengunakan metode Euler sebagaimana yang digunakan oleh Fajar et al. [5] untuk mensimulasikan asas Torricelli pada sebuah bejana serta oleh Wijaya et al. [6] untuk membandingkan hasil penyelesaian persamaan diferensial biasa. Pada dasarnya terdapat beberapa metode numerik yang sering digunakan untuk menghitung solusi persamaan differensial biasa, antara lain metode Euler, Heun, Deret Taylor, dan Runge-Kutta bertingkat [7], $\mathrm{Ng}$ et al. [8] juga menggunakan Hukum Torricelli untuk mengeringkan drainase dengan sistem pemodelan numerik, namun pada penelitian ini hanya berfokus pada metode Euler saja. Metode Euler disebut juga metode orde pertama karena pencarian dalam persamaannya hanya mengambil sampai orde pertama saja. Metode Euler juga menggunakan bantuan dari deret Taylor [9]. Perhitungan numerik dilakukan untuk mengetahui besar volume pada tangki A dan B menggunakan beberapa skenario nilai $C_{1}$ dan $C_{2}$ dengan tujuan untuk mendapatkan model yang paling mendekati kebenaran. Simulasi numerik dilakukan menggunakan aplikasi microsoft excel dengan menerapkan persamaan (9) dan (10).

$$
\begin{aligned}
& V A_{i+1}=V A_{i}+\frac{\partial A}{\partial t} t \\
& V B_{i+1}=V B_{i}+\frac{\partial B}{\partial t} t
\end{aligned}
$$

\section{HASIL DAN PEMBAHASAN}

\subsection{Nilai Konstanta $C_{3}$ (Debit Pompa)}

Sesuai dengan prosedur penelitian yang dijelaskan pada Bab Metode Penelitian, nilai konstanta $C_{3}$ dapat diketahui melalui observasi. Nilai $C_{3}$ bersifat tetap karena pompa mengalirkan debit air secara konstan dengan syarat kecepatan putarnya tetap. Hasil pengukuran debit air pompa disajikan pada Tabel 1. 
Tabel 1 Hasil pengamatan volume tangki A

\begin{tabular}{ccc}
\hline Waktu (s) & Volume tangki A (liter) & $\begin{array}{c}\text { Nilai debit } C_{3} \\
\text { (liter/s) }\end{array}$ \\
\hline 0 & 15.0 & - \\
3 & 15.5 & 0.16667 \\
6 & 16.0 & 0.16667 \\
9 & 16.5 & 0.16667 \\
11 & 17.0 & 0.25000 \\
14 & 17.5 & 0.16667 \\
17 & 18.0 & 0.16667 \\
20 & 18.5 & 0.16667 \\
24 & 19.0 & 0.12500 \\
26 & 19.5 & 0.25000 \\
30 & 20.0 & 0.12500 \\
\hline
\end{tabular}

Pengamatan dilakukan per tiga detik agar didapatkan pembacaan skala yang lebih jelas. Dengan memasukkan nilai $V A$ dan $t$ ke dalam persamaan (4) maka nilai $C_{3}$ diperoleh. Untuk mendapatkan hasil rata-rata maka penghitungan nilai $C_{3}$ dilakukan dari detik ke nol sampai 30 detik. Sehingga diperoleh nilai rata-rata $C_{3}$ yaitu 0.175 liter/s.

\subsection{Nilai Konstanta $C_{1}$ dan $C_{2}$}

Nilai konstanta $C_{1}$ dan $C_{2}$ diperoleh dengan cara observasi dan pengukuran secara langsung pada sistem instalasi air. Sistem aliran air dijalankan sebagaimana prosedur yang telah dijelaskan, dimana air secara kontinyu dipompa dengan debit yang telah diketahui yang dinotasikan sebagai $C_{3}$ sehingga masuk ke tangki A. Kemudian air keluar dari tangki A melalui valve 2 ke tangki B dan dari tangki B dialirkan ke tangki $C$ melalui valve 3 . Untuk mendapatkan nilai $C_{1}$ dan $C_{2}$ dibutuhkan perhitungan dengan menggunakan persamaan (5), (6), (7) dan (8). Pada penelitian ini, pengamatan perubahan volume pada tangki A dan B dilakukan per 10 detik. Dari hasil Tabel 2 dapat dilihat bahwa nilai rata-rata untuk $C_{1}$ adalah 0.01312 sedangkan nilai $C_{2}$ adalah 0.01093 .

Tabel 2 Hasil observasi perubahan volume air tangki A dan B

\begin{tabular}{|c|c|c|c|c|c|c|}
\hline$t(s)$ & A (1) & $\partial V A / \partial t$ & B (1) & $\partial V B / \partial t$ & $C_{1}$ & $C_{2}$ \\
\hline 0 & 15 & -0.025 & 16 & 0.025 & 0.01356 & 0.01077 \\
\hline 10 & 14.75 & 0 & 16.25 & 0.025 & 0.01186 & 0.00909 \\
\hline 20 & 14.75 & -0.025 & 16.5 & 0 & 0.01379 & 0.01212 \\
\hline 30 & 14.5 & 0 & 16.5 & 0 & 0.01207 & 0.01061 \\
\hline 40 & 14.5 & 0 & 16.5 & 0.025 & 0.01207 & 0.00896 \\
\hline 50 & 14.5 & 0 & 16.75 & 0 & 0.01207 & 0.01045 \\
\hline 60 & 14.5 & 0 & 16.75 & 0 & 0.01207 & 0.01045 \\
\hline 70 & 14.5 & -0.01 & 16.75 & 0 & 0.01285 & 0.01104 \\
\hline 80 & 14.4 & -0.01 & 16.75 & 0 & 0.01294 & 0.01104 \\
\hline 90 & 14.3 & -0.02 & 16.75 & 0 & 0.01383 & 0.01164 \\
\hline 100 & 14.1 & -0.01 & 16.75 & 0 & 0.01321 & 0.01104 \\
\hline 110 & 14 & 0 & 16.75 & 0 & 0.01250 & 0.01045 \\
\hline 120 & 14 & -0.01 & 16.75 & 0 & 0.01331 & 0.01104 \\
\hline 130 & 13.9 & -0.015 & 16.75 & 0 & 0.01382 & 0.01134 \\
\hline 140 & 13.75 & -0.025 & 16.75 & 0 & 0.01481 & 0.01194 \\
\hline 150 & 13.5 & 0 & 16.75 & 0 & 0.01296 & 0.01045 \\
\hline 160 & 13.5 & -0.025 & 16.75 & 0 & 0.01509 & 0.01194 \\
\hline 170 & 13.25 & -0.025 & 16.75 & 0 & 0.01538 & 0.01194 \\
\hline 180 & 13 & - & 16.75 & - & - & - \\
\hline \multicolumn{5}{|c|}{ Rata-rata } & 0.01323 & 0.01091 \\
\hline
\end{tabular}




\subsection{Hasil Pemodelan Sistem Persamaan Diferensial Linear dan Simulasi Numerik}

Nilai-nilai yang telah diperoleh berdasarkan hasil perhitungan yaitu $C_{1}, C_{2}$ dan $C_{3}$ kemudian dimasukan ke dalam persamaan (2) dan (3) untuk membangun initial model persamaan diferensial dalam kasus aliran air bertingkat ini. Model persamaan diferensial dari sistem instalasi air ini dapat dilihat pada persamaan (11) dan (12).

Selanjutnya, model yang telah dibangun diuji secara numerik mengunakan metode Euler. Perhitungan numerik dilakukan untuk mengetahui profil perubahan volume air pada tangki A dan B menggunakan beberapa skenario nilai $C_{1}$ dan $C_{2}$ dengan tujuan untuk mendapatkan model yang paling mendekati kebenaran. Sementara itu, skenario simulasi numerik ditunjukan pada Tabel 3. Nilai-nilai $C_{1}$ dan $C_{2}$ diambil dari nilai yang didapat pada hasil pengukuran (Tabel 2) dimana skenario 1 merupakan nilai rata-rata dan skenario 2-4 diambil secara random dari Tabel 2.

$$
\begin{aligned}
& \frac{\partial V A}{\partial t}=0.175-C_{1} V A \\
& \frac{\partial V B}{\partial t}=C_{1} V A-C_{2} V B
\end{aligned}
$$

Tabel 3 Skenario nilai konstanta pada simulasi numerik

\begin{tabular}{ccc}
\hline Skenario & $C_{1}$ & $C_{2}$ \\
\hline 1 & 0.01323 & 0.01091 \\
2 & 0.01333 & 0.01094 \\
3 & 0.01356 & 0.01212 \\
4 & 0.01356 & 0.01091 \\
\hline
\end{tabular}

\subsection{Perbandingan Metode Numerik dan Eksperimental}

Hasil simulasi numerik dari keempat skenario yang telah dibangun beserta hasil eksperimen volume air pada tangki A dan B disajikan pada Gambar 3.

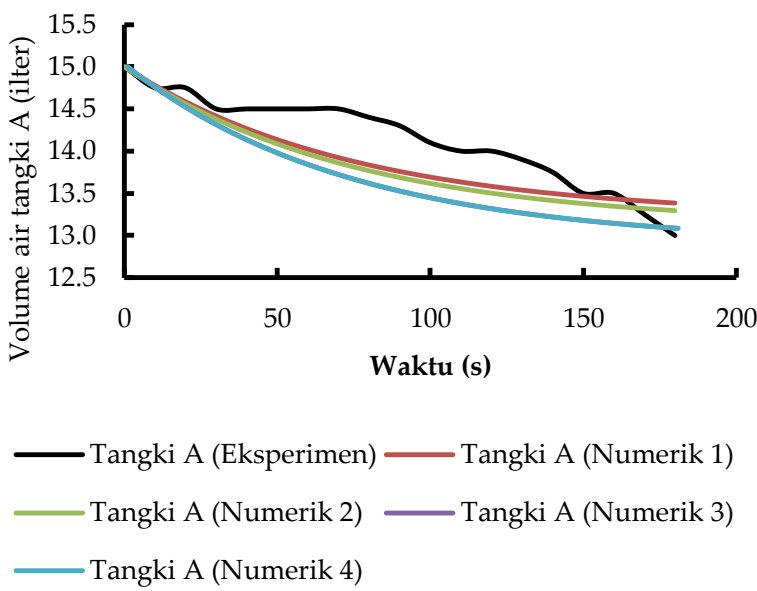

(a)

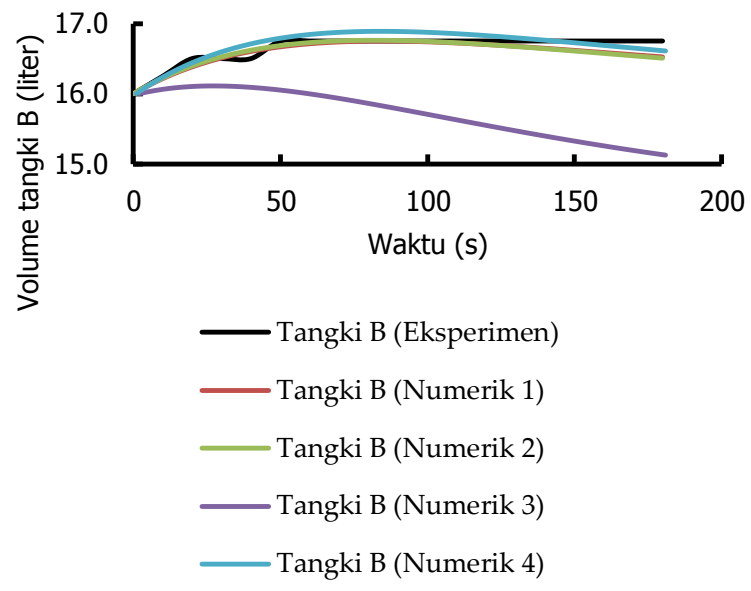

(b)

Gambar 3 Perubahan volume air dalam tangki hasil eksperimen dan numerik: (a) tangki A; (b) tangki B

Berdasarkan Gambar 3, terlihat bahwa skenario yang paling mendekati dengan kurva hasil eksperimen adalah skenario 1,2 dan 4. Namun, untuk menentukan skenario terbaik, diperlukan perhitungan root mean square error (RMSE) dimana semakin kecil nilainya maka semakin baik suatu model [10]. Hasil perhitungan RMSE setiap skenario disajikan pada Tabel 4. 
Tabel 4 Hasil perhitungan nilai RMSE setiap skenario

\begin{tabular}{cc}
\hline Skenario & RMSE \\
\hline 1 & 0.2599 \\
2 & 0.2933 \\
3 & 0.8509 \\
4 & 0.3836 \\
\hline
\end{tabular}

Berdasarkan Tabel 4, model yang menghasilkan nilai RMSE paling kecil adalah skenario 1 dengan nilai 0.2599 sehingga model skenario 1 merupakan model yang paling bagus. Hasil simulasi menggunakan metode Euler ini sudah bagus sebagaimana analisa numerik yang telah dilakukan oleh Fajar et al. [6] dimana menghasilkan error dibawah 2\% saja. Dengan demikian, hasil simulasi numerik dalam kasus peneliterian ini merupakan gambaran ideal dari perubahan volume air pada tangki A dan $\mathrm{B}$ setiap satuan waktu. Namun pada kenyataanya, hasil eksperimen menunjukkan kurva yang tidak halus karena adanya faktor yang mempengaruhi keakuratan hasil pengukuran mulai dari skala terkecil alat ukur volume air, kurang presisi dalam pengukuran waktu dan pengamatan volume air khususnya yang dilakukan secara manual dengan mata. Namun demikian, hasil eksperimen dan simulasi terlihat memliki pola yang hampir sama sehingga model SPDL telah mampu menggambarkan kondisi laju perubahan volume air tangki A dan B secara kontinyu. Dari hasil simulasi 4 skenario, model yang memang paling sesuai dalam menggambarkan kasus sistem aliran air pada tangki bertingkat ini adalah skenario 1 dengan nilai $C_{1} 0.01323$ dan $C_{2}$ 0.01091. Persamaan dari model ini dapat dilihat pada persamaan (13) dan (14).

$$
\begin{aligned}
& \frac{\partial V A}{\partial t}=0.175-0.01323 V A \\
& \frac{\partial V B}{\partial t}=0.01323 V A-0.01091 V B
\end{aligned}
$$

Grafik laju perubahan volume dari tangki A dan B disajikan pada Gambar 4. Terlihat bahwa hasil ekperimen menunjukkan ada hasil yang fluktuatif. Hal ini terjadi sebagimana faktor yang telah dijelaskan sebelumnya yaitu faktor kepresisian alat ukur dan faktor pengamatan yang kurang akurat. Secara umu, hasil simulasi telah mampu menggamabarkan laju perubahan volume pada tangki A dan B dan yang paling mendekati hasil eksperimen adalah skenario 1.

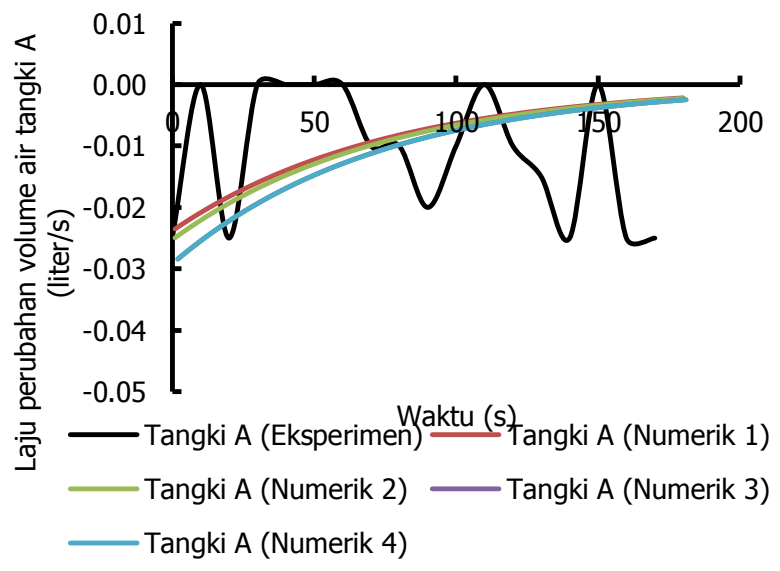

(a)

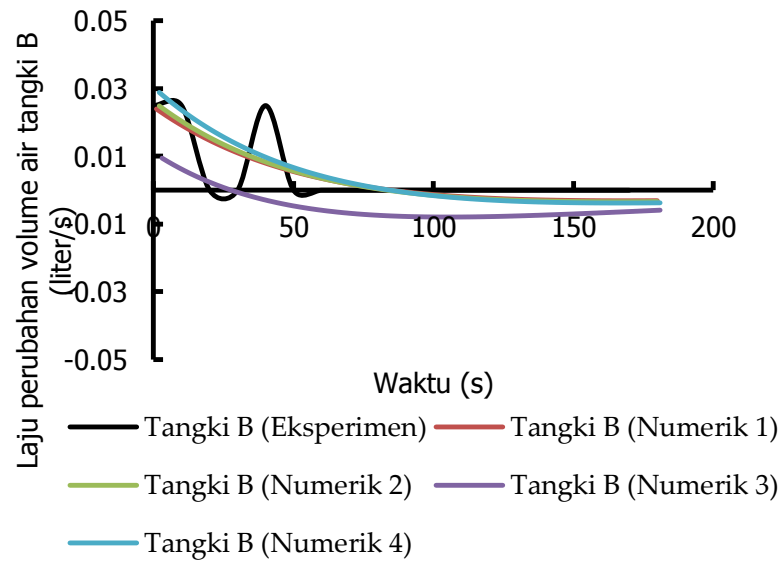

(b)

Gambar 4 Perbandingan laju perubahan volume tangki A dan B secara eksperimen dan numerik 


\section{Kesimpulan}

\subsection{Kesimpulan}

Dari hasil perbandingan metode eksperimental dan metode numerik yang mengaplikasikan sistem persamaan diferensial linear, dapat disimpulkan bahwa kondisi volume air tangki A dan B serta laju perubahan volume airnya setiap satuan waktu menunjukkan tren yang hampir sama. Hasil terbaik diperoleh pada skenario 1 dengan nilai $C_{1}$ dan $C_{2}$ bertutur turut adalah 0.01323 dan 0.01091 dimana nilai RMSE pada skenario ini merupakan yang paling kecil yaitu 0.2599. Adapun ketidakakuratan hasil eksperimen terjadi karena pengukuran dilakukan sesuai kondisi di lapangan yang mana alat ukur volume air memiliki tingkat keteliatian rendah dan pengamatan dilakukan secara manual menggunakan mata. Hasil simulasi numerik metode Euler dengan mengpalikasikan SPDL telah mampu menggambarkan kondisi ideal sistem aliran air bertingkat sehingga dapat kondisi volume air dan laju perubahan volumenya dapat diprediksi mendekati kondisi sebenarnya.

\subsection{Saran}

Pengukuran secara eksperimen perlu dilakukan menggunakan alat ukur yang lebih presisi dan menggunakan data logger yang mampu merekam data secara simuliteran dan menghindari kesalahan pengamatan.

\section{REFERENCES}

[1] Kreyszig E. Advanced Engineering Mathematics. 10th ed. New York: John Wiley \& Sons Inc; 2011.

[2] Hadi AN, Djauhari E, Supriatna AK, Johansyah MD. Teknik Penentuan Solusi Sistem Persamaan Diferensial Linear Non-Homogen Orde Satu. Jurnal Matematika. 2019;18(1):29-40.

[3] Sumithra B. Engineering Applications of Differential equations. nternational Journal Application or Innovation in Engineering \& Management. 2017;6(7):110 -114.

[4] Setiawan A. Pengantar Metode Numerik. Yogyakarta: Andi Yogyakarta; 2006.

[5] Fajar DM, Wibowo HAC, Putri WA. Simulasi asas Torricelli menggunakan visual basic for application (VBA) pada microsoft excel. Prosiding Simposium Nasional Inovasi Pembelajaran dan Sains; 2014.

[6] Wijaya JY, Liong TH, Wardani KRR. Perbandingan Penyelesaian Persamaan Diferensial Biasa Menggunakan Metode Backpropagation, Euler, Heun, dan Runge-kutta Orde 4. Jurnal Telematika. 2015;11(1):1-6.

[7] Munir R. Metode Numerik. 3rd ed: Informatika; 2010.

[8] Ng KC, Ng YL, Lam WH. Particle simulation and flow sequence on drainage of liquid particles. Computers \& Mathematics with Applications. 2013;66(8):1437-51.

[9] Chapra SC. Numerical Methods for Engineers With Personal Computer Application. 2nd ed. New York: McGraw Hill College; 1988.

[10] Saputra TW, Waluyo S, Septiawan A, Ristiyana S. Pengembangan model prediksi laju pengeringan pada irisan wortel (Daucus carota) berbasis regresi linier berganda (RLB) dan jaringan syaraf tiruan (JST). Jurnal Ilmu Rekayasa Pertanian dan Biosistem. 2020;8(2):209-218. 